\section{Pehr Edman}

Dr Pehr Edman, FRS, died on 19 March 1977, in Munich, at the age of 60. In an eventful and distinguished scientific career on three continents, he was undeniably one of the most influential figures in advancing our understanding of the chemical structure of proteins.

Pehr Edman was born in Stockholm on 14 April 1916. Though his undergraduate training was in medicine, very early on he was attracted to the field of biological chemistry, then in its infancy, and in the 1940 s carried out (with U. S. Von Euler and E. Jorpes) some of the earliest work on the chemical characterisation of angiotensin. $\mathrm{He}$ later spent a year at the Rockefeller Institute in the laboratory of John $\mathbf{H}$. Northrop, studying the effects of tyrosinase on several proteolytic enzymes.

In retrospect it is difficult to envisage the primitive state of methods for peptide analysis at that time. An amino acid analysis of a protein was a major undertaking; sequence analysis of even a small peptide was a chemical tour de force. Pehr Edman clearly recognised the need for beter analytical techniques for proteins, and was to devote almost his whole scientific career to developing them.

He approached this task with thoroughness and attention to detail illuminated by a clarity of thought characteristic of the man. His critical insight was to see that earlier attempts at an end group procedure for peptides by Max Bergmann and Emil Abderhalden could be converted into a sequential degradation procedure by simply substituting sulphur for oxygen in the reagent used. This led to one of the most important, (and most often cited) papers in modern biological literature: 'A Method for the Determination of the Amino Acid Sequence in Peptides' published in Acta Chemica Scandinavica in 1950.

From this point Edman's international reputation was established, and he could easily have taken the method as it then was and applied it to structural studies on proteins of biological interest. High honours would have surely and rapidly followed, as they did to others. (Sanger, earlier, and Moore, Stein, Anfinsen and Edelman, later, received Nobel Prizes for their studies on protein structure and function). Pehr Edman typically took a more difficult road. He set out to perfect the sequential degradation method, a task that was to occupy the rest of his life. The way he went about this is in itself a fascinating story. Suffice it to say that in 1967, with a talented colleague in Melbourne, G. Begg, he published in the first issue of the European Journal of Biochemistry an article describing an instrument, the 'sequenator,' for the automatic determination of sequences in proteins. This instrument is now produced commercially and is in use in many laboratories around the world. Its availability has vastly accelerated progress in molecular biology. For this work Pehr Edman was awarded in 1971 the Commonwealth Brittania Award, and the rare Berzelius Gold Medal (the eighth awarded this century). In 1974 he was elected to the Royal Society of London.

At a personal level Pehr Edman was an interesting and complex man. Close or intimate relationships were rarely established even by those who worked in the same field or who followed his methods closely. I was privileged to be one of a small number of his students and close associates. These included John Sjoquist, Birger and Margareta Blombäck, Agnes Henschen (later his wife), Frank Morgan, and of course his colleague for fifteen years, Geoffrey Begg. Pehr rarely spoke of personal matters, but it seems that the end of his first marriage in divorce and some disappointments in local recognition and advancement in Sweden may have contributed to his decision to move to Melbourne in 1957 as Director of St Vincent's Hospital School of Medical Research.

Initially this must have been more a self-imposed exile than a positive career decision. The laboratories at St Vincent's prior to his arrival were nonexistent. Apart from the late Professor John Hayden and one or two others, the staff at St Vincent's in 1957 had little idea of the real potential of Edman's work or of his outstanding scientific abilities. As his work had no obvious immediate clinical relevance he was largely ignored by the hospital. Pehr Edman's reserved, not to say withdrawn, personality contributed to this. The end result was that he worked for many years in virtual isolation both from St Vincent's Hospital and with a few exceptions from the Australian scientific community. $\mathrm{He}$ gained at least the local reputation of being un- sociable and difficult. On the contrary, he was, I believe, a rather shy person who simply did not have the sort of extroverted nature required to make his presence felt in the scientific wilderness of Australia in which he found himself.

To his close associates and friends, and to scientific visitors to his laboratory he was a totally different manwarm, helpful and unfailingly courteous. However, he was uncompromising in his attitude to anything he regarded as scientifically unsound. In his own work he was overwhelmingly competent. He enjoyed working at the bench, designed and made his own instruments and was an excellent glassblower. In the European tradition, the laboratory was run on disciplined lines. No short-cuts or shoddy techniques were tolerated. He put great emphasis on self-reliance and careful use of equipment. At least in the early days in Australia he refused to buy the commercially produced micropipettes of Lang-Levy design. Each was made and calibrated in the laboratory and kept with scrupulous care. Chemicals were never used straight out of the bottle; before each experiment began he would personally carry out a careful redistillation or recrystallisation of the required reagents. His approach was totally professional.

Pehr Edman was a man of cultivation, widely read, interested in music and the arts, and a gourmet cook. At morning and afternoon tea breaks at work his ritual was to sit down, light one of his favourite thin cigars and slowly drink a cup of very strong freshly ground coffee. The conversation, usually unrelated to science, reflected his wide interests and cosmopolitan attitudes.

Though at first he must have felt the scientific and personal isolation in Australia, Pehr grew to love his country of adoption and later became an Australian citizen. He panticularly enjoyed fishing and bird-watching, and few scientific visitors from overseas escaped a day-long excursion to Sherbrooke Forest, near Melbourne, to catch a glimpse of the elusive Australian lyre bird.

In 1972 he left Australia for Munich to be head of a new protein chemistry unit at the Max-Planck-Institut für Biochemie at Martinsried. Unhappily he did not long survive in this new venture. He leaves a wife, Dr Agnes 
Henschen-Edman, and two young children, Carl and Helena.

Though his career was tragically cut short, he succeeded brilliantly in the task he set himself. One wonders what scientific problem would not have succumbed to Pehr Edman's creative and single-minded endeavours.

H. D. Niall

\section{J. Smithells}

DR Colin J. Smithells who died on 25 March 1977, held a variety of posts in the metallurgical field since he graduated in chemistry at Leeds University in 1914.

Immediately after graduation he joined the Army in which he served with distinction throughout the 191418 war reaching the rank of Major in the Gloster Regiment, gaining the Military Cross and being mentioned in dispatches.

In 1919 he joined the research staff of the General Electric Company at the new laboratories being set up by Sir Clifford Patterson at Wembley. There he was primarily responsible for the production and fabrication (by the new metallurgical techniques such as powder metallurgy) of the less wellknown metals-with particular reference to tungsten and the manufacture of lamp filaments, receiving valves etc. His book Tungsten continues to hold the field and other books, such as Gases in Metals have established with authority the existing state of knowledge at the time they were written.

$\mathrm{He}$ was awarded the degree of DSc. by Leeds University in 1921. While still at GEC in 1937 he developed a Heavy Alloy (of tungsten nickel and copper) particulars of which were first published in Nature in 1937.

In 1938 he left the GEC to become General Manager of Lodge Plugs of Rugby where he was concerned with the use of platinum alloys until 1944 when he was appointed Director of Research of the British Aluminium Company. Here he was responsible for the setting up of the Company's new and now well-known Research Laboratories at Chalfont Park in Buckinghamshire.

In 1956 he retired from Chalfont Park to become Managing Director of Magnesium Elekton Limited, which post he held until he finally retired in 1963.

Throughout his working life he devoted time generously to the work of organisations which aimed to benefit the industry and profession of metallurgy. He was, in 1945, a Founder Fellow of the Institution of Metallurgists, of which he was President in 1951-52. In the following year he was President of the Institute of Metals and throughout gave much time to the work of government committees and industrial bodies such as the British Non-Ferrous Metals Research Association and the Aluminium Development Association. In 1949 he edited the first issue of the Metals Reference Book, a comprehensive collection of data which he saw through several new editions.

$\mathrm{He}$ was outstanding in the profession for his charm of manner and clarity of thought and speech and will be a great loss. He is survived by his wife Mary, two sons and three daughters.

G. L. Bailey

\section{R. N. Singh}

Professor R. N. Singh, formerly Head of the Botany Department of Banaras Hindu University, died from heart failure on March 9, 1977. $\mathrm{He}$ was internationally recognised as an authority on phycology, to which he contributed much original observation and in which he initiated new lines of research. Especially, he was distinguished for his work on nitrogen fixation by blue-green algae in rice fields, making contributions both to botanical knowledge and practical agriculture. Besides isolating and characterising various nitrogen-fixing species, he was one of the first to study the paddy field as an ecosystem. His use of the simple expedient of enclosing areas of alkaline "Usar" lands, so that ponds form in the rainy season and prolific growth of blue-green algae is encouraged, is a method of reclamation the full potential of which has not yet been realised. This and other work is described in his book, Role of bluegreen algae in nitrogen economy of Indian agriculture (1961). He also carried out research on the taxonomy, morphology, physiology, radiation biology, genetics and virology of bluegreen algae. In the course of this work he produced many mutant strains of blue-green algae, which have interesting implications for our understanding of morphogenesis in these organisms.

R. N. Singh was born on August 2, 1915 , in the Deoria district of Uttar Pradesh and was educated at the U.P. College, Varanasi and Even Christian College, Allahabad. He obtained the M.Sc. degree in 1938 at the Banaras Hindu University while working under Professor Y. Bharadwaja. In 1946 he was awarded the D.Sc. of the same University. He worked in several famous laboratories abroad including the Department of Botany, University College London, the Department of Biochemistry, University of Wisconsin (where he participated in the preparation of the first cell-free extracts active in nitrogen fixation), and the Plant Research Laboratory, Michigan State University. He travelled widely and was a familiar figure at international conferences on phycological and limnological topics.

Besides being a creative research worker, Professor Singh was an outstanding teacher of plant physiology as well as phycology and many of his students now hold responsible posts in different parts of the world. $\mathrm{He}$ established a well equipped phycological laboratory in the Banaras Hindu University where he trained more than thirty Ph.Ds in various branches of phycology. After retirement he occupied himself with writing on recent developments in the study of bluegreen algae. It is to be hoped that these nearly completed works will be published in due course. His sudden death is a sad loss to Indian science and phycology generally. He will be remembered with affection and gratitude by his many friends and students.

P. K. Singh

G. E. Fogg

\section{Eli Lilly}

Eli Lilly, former President and Chairman of Eli Lilly and Company of Indianopolis died on 24 January at the age of 91 . He was a very remarkable man. From the age of 10 he workel with his father Josiah K. Lilly Senior, in the family business and in 1907 qualified as a pharmaceutical chemist from the Philadelphia College of Pharmacy and Science, where his lather also had studied. Thereafter he developed an interest, ahead of his time, in efficiency of production methods, becoming superintendent of the manufacturing division in 1909, general superintendent in 1915, and vicepresident from 1920 until 1932 when he succeeded his father as president. He guided the company through the difficult Depression years of the eariy 1930s and despite the economic downturn no employees were laid off. Under his overall guidance the production of insulin for diabetes was developed in the 1920 s, the production of liver extract for pernicious anaemia, and of barbiturates, in the 1930s; and after the war production of penicillins and other antibiotics including erythromycin.

Lilly was a great philathropist. $\mathrm{He}$ endowed a memorial laboratory in 1936 at the Philadelphia College of Pharmacy and founded Lilly Endow. inent, lnc. in 1937 which over the years has given some 250 million dollars to charitable causes. His wideranging interests inciuded educational and civic activities, stock-breeding and archaeology. His wife died in 1973 and their daughter in 1970 . There are no immediate survivors.

Frank Hartley 